\title{
Indonesia's Defense Economic Program in the Context of Food Security, Overcoming the Impact of the Covid-19 Pandemic and Anticipating the Impact of Climate Change
}

\author{
Ivan Yulivan \\ Universitas Pertahanan RI, Kawasan IPSC Sentul, Sukahati, Kec. Citeureup, Kabupaten Bogor, \\ Jawa Barat - Indonesia 16810
}

\begin{abstract}
Apart from the Covid-19 pandemic, there are other threats that will be faced by countries around the world, including Indonesia, namely climate change. The threat of climate change is predicted to cause a worldwide food crisis. One of the government programs through the ministry of defense is the food estate program. This study aims to analyze the strategies used by the government in the development of food estates in strengthening the national economy. This research is qualitative. The data collection technique was carried out using a literature review. The author relates the discussion to the strategy theory proposed by Carl Von Clauswitz. There are 3 war strategies used by Napoleon Bonaparte in battle and his war experience, namely Means, Way, and Ends. Based on this research, the results show that there are 3 strategies used by the government in the development of food estates. The first strategy is Means, which is the government's efforts to develop food estate by providing land resources to be developed into a special sector for food estate development. The second strategy is the Way, the Government designs a business model that will be used from the production of food estate development for the recovery of the national economy. The third strategy is Ends, namely the development of food estates based on law number 3 of 2002 concerning national defense.
\end{abstract}

Keywords: Defense Economy, Food Estate, Government, Development, National Economic Recovery, Strategy DOI: $10.7176 / \mathrm{JESD} / 12-23-04$

Publication date: December $31^{\text {st }} 2021$

\section{Introduction}

Economy is the most important part of human life. Economic needs are closely related in everyday life. Humans to meet their needs such as eating, drinking, clothing, shelter, and others require a strong economy. The state is required to regulate policies regarding the Indonesian economy and is required to guarantee the economy of the Indonesian people. The economy is also an important factor in national development because if economic growth is good, then national development will be better too (Hanoatubun, 2020, p. 148). From one period to another the ability of a country to produce goods and services will increase because the production factors are always increasing in quantity and quality (Saputro, Rivai, et al., 2021, p. 105).

In improving welfare, high and sustainable economic growth is needed. Long-term economic development is expected to bring about fundamental changes in the economic structure that trigger economic growth (Saputro, Tarigan, et al., 2021, p. 330). The current economic crisis has hit globally due to the negative impact of the Covid19 pandemic. Various countries use effective ways to solve problems that occur in the economic sector. Indonesia has also not been spared the impact of the Covid-19 pandemic. The strategy used by Indonesia is to implement the National Economic Recovery program. The program is one of a series of activities to reduce the impact of Covid19 on the economy. The National Economic Recovery aims to protect, maintain, and improve the economic capacity of business actors in running their businesses during the Covid-19 pandemic (Ministry of Finance, 2020).

The development of a food estate is one of the solutions and strategies taken by the government to implement the national economic recovery program. This program was formed due to the massive impact of the COVID-19 pandemic being felt by all levels of Indonesian society, the sector most affected by this pandemic is the economic sector. In the operational plan for the national economic recovery for the food estate, it is explained that the establishment of the food estate itself is one of the programs implemented by the government and is described in government regulation number 23 of 2020 concerning the national economic recovery program for handling the COVID-19 pandemic (Directorate of Inauguration and Administration). Forest Area \& Directorate General of Forestry Planning and Environmental Management, 2020).

Agriculture is one of the spearheads of life in a country. From its development, agriculture is divided into many sectors that focus on their own production. Agriculture also affects the economic development of a country where the results produced from the agricultural sector can be useful for the food security of a country and the export of agricultural products. At a time when the COVID-19 pandemic hit all aspects globally, the agricultural sector was in the spotlight because of the threat of a food crisis that continued to loom over every country. The impact that is felt by farmers is high enough demand, quality assurance of production quality, distribution channels, and many other aspects that must be considered to meet the food needs of the community during this pandemic. 
Therefore, an effective strategy adjustment is needed in solving these problems (Wulandari \& Anggraini, 2020, p. 387).

Indonesia has a high potential in the agricultural food sector. This should be the government's priority in developing food crop commodities such as rice, corn and soybeans. Efforts to increase the production of food and other agricultural products need to be carried out in line with the increasing population and global economic competition which affects the consumptive level of food production (Hidayat, 2009, p. 108). With so many fertile areas for growing food crops, Indonesia can overcome food and economic problems that occur with clear policies, especially in resolving the negative impacts caused by the Covid-19 pandemic, which is able to accelerate national economic recovery and national defense. Therefore, the food estate becomes a reference for the national economic recovery program in order to form an economic defense that can deal with incoming threats.

The definition of Food Estate itself is a popular term for large-scale ( $>25$ ha) plant cultivation activities carried out with industrial agricultural concepts based on science and technology, capital, as well as modern organization and management (Agricultural Research and Development Agency, 2011). The food estate program is implemented in various regions in Indonesia, including Central Kalimantan, Papua, North Sumatra and South Sumatra. The government is trying to develop a food estate to solve the problem of the threat of a food crisis and to boost the national economic recovery both during the pandemic and after the Covid-19 pandemic.

Economic resilience is one of the main elements of national resilience. Talking about national security, we cannot be separated from the economic capacity of a country (Saputro \& Meirinaldi, 2021, p. 2). The Ministry of Defense is the Leading Sector in developing a food estate in Central Kalimantan. According to the Spokesperson for the Minister of Defense for Public Communication and Inter-Agency Relations Dahnil Anzar Simanjuntak stated that the appointment of the Ministry of Defense as the leading sector for food estate development is based on Law number 3 of 2002 concerning national defense (CNN Indonesia, 2020). To achieve a strong defense economy, security stability is required. Security stability, as one element of the institution - which is one of the pillars that determine the level of productivity (competitiveness) of a country, is important for business and forms a strong basis for competitive growth. As a parameter of the condition of a country's institutional environment, security depends on the efficiency and behavior of stakeholders from the public sector (Saputro \& Meirinaldi, 2019, pp. 237-238). Not only that, the Ministry of Defense in developing food estates in Central Kalimantan is also in synergy with the Ministry of Public Works and Public Housing, the Ministry of Agriculture, the Ministry of Environment and Forestry, and the Ministry of State-Owned Enterprises (Djoko, 2020, p. 8). Based on the introduction above, the writer is interested in writing an article about the food estate development strategy in the national economic recovery.

\section{Research Methods}

The writing method in this article is a qualitative research that uses a literature study approach. Literature study is the beginning of the data collection method. Literature study is a data collection method that is directed at searching for data and information through documents, both written documents, photographs, pictures, and electronic documents related to the food estate development program and the legal basis of law number 3 of 2002 concerning national defense in order to support the writing process (Sugiyono, 2005, p. 83). The author processed the data obtained using descriptive analysis method as a form of collecting and analyzing data. In the process of this research, the author tries to link the relationship between the development of food estate which is included in the national economic recovery program with law number 3 of 2002 on national defense.

The theory used by the author to deepen his writing is the theory of strategy written by Carl Von Clausewitz which explores the war strategies used by Napoleon Bonaparte in battle and his war experiences. There are 3 things that are included in the elements of war, namely:

1. Emphasizes the need to concentrate power (ends) at the "decisive point" of the battle (Supriyatno, 2017, p. 254). 2. the shock value of the ways (strategy) against the enemy (Supriyatno, 2017, p. 260).

3 . The application of means (resources), namely power on a large scale and aggressively (Supriyatno, 2017, p. 270).

In formulating the strategy, it is necessary to understand the objectives (Ends), concepts (Ways), instruments (Means) of the food estate program development. Strategy must be driven by goals (Ends) and not by resources (Means) to ensure effective opportunities to achieve them. Therefore, Goals (Ends) and strategic concepts (Ways) are influenced by the availability of resources (Means). But goals (Ends) and strategic concepts (Ways) are still influenced by the availability of resources (Means) (Eko PB et al., 2018, p. 6).

\section{Discussion}

3.1. Food Crisis Impacts climate change

The climate crisis will definitely have an impact on food availability. The worst impact of the climate crisis that we might receive is that food will become scarce, prices will soar and crops will lose their nutritional value.

There are at least four major impacts of the climate crisis on agriculture. First, erratic seasonal changes such 
as prolonged dry spells and unpredictable rainfall can have an impact on crop failure resulting in reduced food supply and reduced community nutrition (climate commitment, 2021).

Changes in weather patterns such as a prolonged dry season that causes drought and a rainy season that is difficult to predict can lead to a food crisis. Especially in agricultural granary areas whose irrigation sources depend on rainwater

Second, the climate crisis has the potential to cause extreme droughts which nationally can cause the national rice supply to drastically decrease. According to Professor of the Bogor Agricultural Institute, Dwi Andreas Santosa (2019), he estimates that the decline in rice production will reach 2 million tons.

Third, globally, food shortages due to the climate crisis will result in a humanitarian crisis due to a lack of food availability.

The United Nations (2019) stated that the climate crisis has threatened the world's food supply. More than $10 \%$ of the world's population is currently malnourished and the climate crisis will exacerbate the situation.

This is illustrated by a report published by the World Food and Agriculture Organization (FAO) (2019) which reveals the adverse effects of global climate change. The report was compiled by 100 scientists from 52 countries and reveals that if the climate crisis is left unchecked, rising temperatures, extreme weather and land subsidence could trigger a global food crisis.

Cynthia Rosenzweig, who is one of the 100 experts, said that due to climate change, the risk of world food failure is increasing, which will occur at the same time, causing a crisis.

Fourth, the climate crisis will require farmers to adapt. One of them is the use of water-saving technology so that in the event of a water crisis, agriculture can still be carried out and utilize information technology such as an integrated planting calendar system.

Unfortunately, adaptation to the use of this technology will be difficult to implement, considering that farmers are used to doing conventional farming so that losses due to the climate crisis to farmers will be difficult to overcome.

Seeing this, the only way to maintain our food availability is to slow down the climate crisis. Countries in the world must support this by issuing policies that support it.

Exploitation of natural resources which has been one of the means of earning money must be accompanied by adequate environmental conservation and protection policies.

Based on the theory written by Clauswitz in the book Supriyatno (2017) there are 3 views related to the elements of war Means, Way, and Ends. The relationship between the food estate development program and the strategic concept is very closely related. The author will describe the strategic points in the food estate development plan for the national economic recovery.

\subsection{Means Strategy Towards Food Estate Development}

Means of Strategy, it will be explained that the strategy can be carried out using currently available resource instruments. In applying the existing resource utilization strategy, the implementation of food estate development requires land resource instruments available in Indonesia. Prior to the current planned food estate program, the previous government had made the same program and implemented it in several locations in Indonesia. In 1995, during the Suharto administration, the government issued Presidential Decree number 82 of 1995 by conducting Peatland Development in Central Kalimantan (Eryan et al., 2020). Then during the Susilo Bambang Yudhoyono administration, food estate development re-emerged with the launching of the Merauke Integrated Food and Energy Estate (MIFEE) program which was approved by the Ministry of Agriculture on 11 August 2010 (Ito et al., 2014, p. 29). The last is a food estate project in Bulungan Regency, North Kalimantan Province with the formation of the Delta Kayan Food Estate which was carried out in 2011 (Obidzinski et al., 2013, p. 953).

The development of a food estate is one of the programs implemented by the government to accelerate the national economic recovery to deal with the current and post-pandemic COVID-19 pandemic as a form of overcoming the threat of a food crisis. In practice, the government is developing food estates in various locations in Indonesia. As stated in the Food Estate National Economic Recovery Operational Plan published by the Agricultural Research and Development Agency, the food estate development location point will be implemented in Central Kalimantan Province using the former Peatland Project covering an area of 770,601 Ha by changing the function of various lands in the Regency/City Kapuas, Pulang Pisau, South Barito, Katingan, and Palangka Raya. Meanwhile in Papua Province, food estate development is empowered in Merauke, Mappi, and Boven Digoel Regencies with a total land area of 2,052,551 Ha. For the Sumatran area, food estate development is empowered in 2 provinces, namely North Sumatra province which focuses on one Humbang Hasundutan district with a land use of 30,000 hectares and in South Sumatra which empowers food estate in several locations in Musi Banyuasin Regency, Pali, North Musi Rawas, Muara Enim, Banyuasin, Ogan Komering Hilir, Palembang City, East OKU, Ogan Komering Ulu, and Musi Rawas with a land use of 235,351 Ha (Agricultural Research and Development Agency, 2011). 
3.3. Way Strategy Towards Business Model Development and National Economic Recovery Food Estate Understanding the Way is a way that is accepted by all parties involved, including also about financing and operational concepts to achieve goals. From Way's strategy, it can be concluded that the financing and operational concepts are focused on the planned business model for production output from the food estate and the budget prepared by the government for the development of the food estate in order to achieve the desired goal. In terms of the planned business model, the Agency for Research and Development and Innovation of the Ministry of Environment and Forestry (BLI KLHK) partnered with International Trade Analysis and Policy Studies (ITAPS) Faculty of Economics and Management (FEM) Bogor Agricultural University (IPB) to design a food security business model and alternative community livelihoods in providing food needs and the sustainability of the peat ecosystem. The head of the BLI study team, Dr. Deden Djaenudin designed a business model that is used to utilize food estate products by using a business canvas model and value chain analysis in order to take advantage of paludiculture as an alternative for community livelihoods. In designing the business model, a socio-economic baseline for the community, institutions, and commodity development is needed (Rahmawati, 2020). The types of commodities that are prioritized in food estate development are rice, corn, soybeans, cassava, sweet potatoes, peanuts, sorghum, fruits, vegetables, sago, palm oil, sugar cane, and cattle or chicken (Badan Litbang). Agriculture, 2011).

Then the budget issued by the government for the development of food estates in the strategic policy of the 2021 APBN is 104.2 trillion with the aim of increasing food production, economic recovery through revitalizing the national food system and developing food estates (Kcaribu, 2020). It is hoped that the budget disbursed by the ministry of finance in building a food estate area will be able to accelerate the national economic recovery due to the negative impact of the COVID-19 pandemic.

\subsection{Ends Strategy Against Food Estate Program Based on Law No. 3 of 2002 on State Defense}

What is the end goal of the desired strategy? The real essence of food estate development aims to accelerate national economic recovery and overcome the threat of a food crisis occurring globally in order to form a strong and independent national defense. The food estate program is part of the government's national economic recovery program in solving economic problems caused by the negative impact of COVID- 19.

President Joko Widodo appointed the Ministry of Defense as the leading sector in the development of the food estate program. The legal basis used for the construction of a food estate refers to Law No. 3 of 2002 concerning food defense. The world is currently overshadowed by an economic crisis and a food crisis that can undermine the stability of global developments, therefore in order to overcome these threats, the Ministry of Defense participates in the food estate program.

Food estate development is closely related to the defense economy. in terms of its objectives, food estate plays an important role in the national economic recovery program in order to maintain stability and national defense from an economic point of view. According to Purnomo Yusgiantoro, defense economics is a branch of science that applies economics to national defense issues. Like development economics, natural resource economics, political economy, and environmental economics, defense economics applies economics that has been used far into certain fields, in this case national defense. Defense in general implies maintaining the existence of the nation and state. Based on law number 3 of 2002 concerning national defense, national defense is defined as an effort to build, use, and foster state sovereignty in order to overcome threats from within and outside the country to defend state sovereignty, territorial integrity of a country, and the safety of the nation (Yusgiantoro). , 2014, p. 3)

Indonesia as a sovereign country views it as important to build a defense force. The form of defense is prepared by synergizing aspects of military defense and non-military defense aspects. Defense facing non-military threats places the Ministries/Institutions $(\mathrm{K} / \mathrm{L})$ as the main element assisted by other elements of the nation's power (Ministry of Defense, 2014, p. 4). Threats that come to a country are not only military-based threats, but threats that can disrupt national defense can occur in the non-military sector. From the development of the food estate, it is expected to be able to overcome the non-military threat in the food sector and accelerate the national economic recovery.

When viewed from the legal basis for the development of food estates, Law No. 3 of 2002 concerning National Defense is very much in line with the essence intended by the government. In Law number 3, several articles are stated. Chapter I general provisions of article 1 paragraph 2 explain that the national defense system is a universal defense system that involves all citizens, territories and other national resources, and is prepared early by the government and is carried out in a total, integrated, directed, and continuous manner. to uphold state sovereignty, territorial integrity, and the safety of the entire nation from all threats. Then it is explained again in paragraph 3, the implementation of state defense is all activities to carry out state defense policies. Paragraph 4 also emphasizes that the management of national defense is all activities at the strategic and policy level which include planning, implementation, supervision, and control of national defense (Law of the Republic of Indonesia Number 3 of 2002 concerning National Defense, 2002, p. 2). Reviewing chapter I of Law No. 3, we get answers 
related to food estate development planning by prioritizing planning in overcoming the threat of crises, then utilizing both human and natural resources. Government policies need to be considered as a reference in the implementation carried out by the various agencies involved, and the Ministry of Defense which acts as supervisor and controller of the food estate program.

Article 6 explains that national defense is carried out through efforts to build and foster the ability, deterrence of the state and nation, as well as overcoming any threats. Article 7 paragraph 3 also emphasizes that the national defense system in the face of non-military threats places government institutions outside the defense sector as the main element, in accordance with the form and nature of the threat faced by the nation supported by other elements of the nation's power (Law of the Republic of Indonesia). Number 3 of 2002 concerning National Defense, 2002, p. 4). The government's efforts always consider future threats, such as the threat of an economic crisis and a nonmilitary food crisis. By placing government agencies as implementers, supervisors and controllers, every component in food estate development planning can be empowered effectively and maximally in order to get the best results and be able to ward off threats that come.

\section{Conclusion}

The threat of a food crisis caused by the COVID-19 pandemic and also climate change is being faced by the Indonesian government with a food estate development program to maintain national defense in the economic sector and food security. The strategic concept (Means) used in development carried out in various regions in Indonesia has become a form of land use to be used as an alternative to new jobs and can increase food security and national economic recovery due to the COVID-19 pandemic. After planning the program, a strategy (Way) is needed by taking into account the business model that will be used so that the maximum utilization of the products produced from the food estate can be utilized to improve the country's economy. And lastly is the strategy (Ends). From the formation of this program, the Ministry of Defense is appointed by the president directly as the leading sector to supervise and control the program so that it is carried out properly and in accordance with the essence of maintaining national defense. If you link the food estate program with Law No. 3 of 2002 on national defense, several articles contained in the law are closely related to national defense. The threats that come are not only military in nature, but from the non-military sector the government must also pay attention to. From a series of strategies planned by the government in carrying out food estate development, it is hoped that the government can carry out the food estate program in order to achieve the expected goals. Considering this, the development of a food estate is able to maintain national defense from threats that lead to a food crisis and economic crisis that comes from within and outside the country, especially in the face of climate change which is predicted to occur in the relatively near future.

Recommendation In developing a food estate, the government needs to consistently pay attention to the direction of the program's development. If at the beginning it only focused on how to solve the threat of a food crisis, the government must also pay attention to the economic value of the food estate production. The essence of the national economic recovery is how to restore the economy as a whole in every part of the country. Since the food estate is part of the program, the government needs to plan for the development of a food estate so that its objectives in overcoming the threat of a food crisis and the recovery of the national economy can go hand in hand. In the application of food estate development, it is expected to be one of the government's programs that can solve problems that occur due to the negative impact of COVID-19 and it is hoped that this food estate program can be maintained in the future in order to form a strong and independent defense economy.

\section{References:}

Badan Litbang Pertanian. (2011). Buku Pintar Food Estate (1st ed.). Badan Penelitian dan Pengembangan Pertanian. https://www.litbang.pertanian.go.id/info-aktual/819/file/Bagian-1.pdf

CNN Indonesia. (2020, July 14). Kemhan: Food Estate Bukan Program Cetak Sawah. CNN Indonesia. https://www.cnnindonesia.com/nasional/20200714193730-20-524676/kemhan-food-estate-bukan-programcetak-sawah

Dipua, A., Harahap, N., Puspitawati, D., Aminuddin, F., Prakoso, L. Y., Brawijaya, U., \& Pertahanan, U. (2021). Sea Defense Strategy the Indonesian Navy in Dealing with the South China Sea Conflict. Italienisch, 11(2), 120-126. https://doi.org/https://doi.org/10.1115/italienisch.v11i2.103

Dipua, A., Hermawa, R., Puspitawati, D., Harahap, N., Nurdiansyah, D. R., Prakoso, L. Y., Hermawan, R., Puspitawati, D., Harahap, N., \& Rizanny, D. (2020). AN ANALYSIS OF THE SOUTH CHINA SEA CONFLICT: INDONESIA'S PERSPECTIVES, CONTEXTS AND RECOMMENDATIONS. PalArch's Journal of Archaeology of Egypt/Egyptology, 17(4), 976-990.

Direktorat Pengukuhan Dan Penatagunaan Kawasan Hutan, \& Direktorat Jendral Planologi Kehutanan Dan Tata Lingkungan. (2020). Rancangan Operasional Pemulihan Ekonomi Nasional (PEN) Food Estate. https://environmentalpaper.org/wp-content/uploads/2021/03/09-Ringkasan-Pemulihan-Ekonomi-NasionalPEN-Food-Estate.pdf 
Djoko, I. E. (2020). Menteri Pertahanan RI Sebagai Leading Sector Dalam Pengembangan Food Estate Bekerjasama Dengan Menteri PUPR dan Mentan. Kementrian Pertahanan, 8. https://www.kemhan.go.id/wpcontent/uploads/2021/06/WIRAbaru2020INDkecil.pdf

Eko PB, E. P., Widodo, P., \& Santosa, A. I. (2018). Strategi Metode Binter Satuan Komando Kewilayahan Untuk Mengatasi Terorisme Di Wilayah KODIM 0735/Surakarta. Jurnal Strategi Dan Kampanye Militer, 4(3), 6. http://jurnalprodi.idu.ac.id/index.php/SMK/article/view/273

Eryan, A., Shafira, D., \& Wogkar, E. E. L. T. (2020). Analisis Hukum Pembangunan Food Estate Di Kawasan Hutan Lindung. https://icel.or.id/wp-content/uploads/ICEL_Seri-Analisis-Food-Estate-Rev.2.opt_.pdf

Hanoatubun, S. (2020). Dampak Covid-19 Terhadap Perekonomian Indonesia. EduPsyCouns: Journal of Education, Psychology and Counseling, 2(1), 148. https://ummaspul.ejournal.id/Edupsycouns/article/view/423

Hidayat, A. (2009). Sumberdaya Lahan Indonesia: Potensi, Permasalahan,Dan Strategi Pemanfaatan. Jurnal Sumberdaya Lahan , 3(2), 108. https://media.neliti.com/media/publications/133835-ID-none.pdf

Ito, T., Rachman, N. F., \& Savitri, L. A. (2014). Power to make land dispossession acceptable: a policy discourse analysis of the Merauke Integrated Food and Energy Estate (MIFEE), Papua, Indonesia. The Journal of Peasant Studies, 41(1), 29. https://doi.org/10.1080/03066150.2013.873029

Kacaribu, F. (2020). Kondisi Perekonomian Dan APBN Terkini. https://www.kemenkeu.go.id/media/16257/v4ka-bkf_dialogue-kita-kli-2-oktober-2020.pdf

Kasih Prihantoro, Arif Darmawan, Zakariya ., Lukman Yudho Prakoso, \& Kasih Prihantoro Zakariya ., Lukman Yudho Prakoso, A. D. (2019). Implementation Study of Public Policies, Synergity of Policy for Defense Area and National Area Spatial in Grati Pasuruan. Public Policy and Administration Research, 9(Public Policy and Administration Researc), 33-39. https://doi.org/10.7176/PPAR/9-11-04

Kementrian Keuangan. (2020). Program Pemulihan Ekonomi Nasional. https://www.kemenkeu.go.id/media/15149/program-pemulihan-ekonomi-nasional.pdf

Kementrian Pertahanan. (2014). Buku Putih Pertahanan Indonesia. Kementrian Pertahanan Republik Indonesia. https://www.kemhan.go.id/itjen/wp-content/uploads/migrasi/peraturan/BUKU PUTIH.pdf

Kasih Prihantoro, Arif Darmawan, Zakariya ., Lukman Yudho Prakoso, \& Kasih Prihantoro Zakariya ., Lukman Yudho Prakoso, A. D. (2019). Implementation Study of Public Policies, Synergity of Policy for Defense Area and National Area Spatial in Grati Pasuruan. Public Policy and Administration Research, 9(Public Policy and Administration Researc), 33-39. https://doi.org/10.7176/PPAR/9-11-04

komitmeniklim. (2021, July 25). Breaking News, Editorial. Retrieved from komitmeniklim.com: https://komitmeniklim.id/bagaimana-nasib-pangan-kita-setelah-terdampak-krisis-iklim/

Lukman Yudho Prakoso Dohar Sianturi, Ratna Damayanti, editor, \& reviewer, E. S. [et al. . (2020). Proceeding KKLN : penguatan pertahanan negara melalui peningkatan keamanan laut di Provinsi Papua dan Provinsi Papua Barat. ISBN : 9786236610428.

Lukman Yudho Prakoso Kasih Prihantoro, S. (2020). URGENCY OF FORMING MARITIME COMMAND CENTER

Lukman Yudho Prakoso Kasih Prihantoro, S., \& editor Suca Rusdian, M. K. (2021). Metode SWOT AHP dalam merencanakan strategi pertahanan [sumber elektronis].

Lukman Yudho Prakoso Sri Sundari, Dindin, editor, \& reviewer, E. S. [et al. . (2021). Proceedings KKDN 2020 Universitas Pertahanan: strategi pertahanan laut menghadapi ancaman di perairan Provinsi Sulawesi Tenggara. ISBN : 9786236610220.

Obidzinski, K., Takahashi, I., Dermawan, A., Komarudin, H., \& Andrianto, A. (2013). Can large scale land acquisition for agro-development in Indonesia be managed sustainably? Land Use Policy, 30(1), 953. https://doi.org/10.1016/j.landusepol.2012.06.018

Prakoso, L. Y. suhirwan; rianto; tri legionosuko; G. Z. (2021). Analysis Public Policy Of Defence Strategy. Journal of Legal, Ethical and Regulatory Issues, August. https://www.abacademies.org/articles/analysis-publicpolicy-of-defence-strategy.pdf

Prakoso, L. Y., \& Aprilliyani, M. (2021). Implementasi Ilmu Teknik Elektro Bidang Pertahanan dan Militer (K. Prihantoro \& S. Suhirwan (Eds.); 1st ed.). CV. Aksara Global Akademia.

Undang-Undang Republik Indonesia Nomor 3 Tahun 2002 Tentang Pertahanan Negara, Presiden Republik Indonesia 2 (2002). https://peraturan.bpk.go.id/Home/Details/44421/uu-no-3-tahun-2002

Rahmawati, I. (2020). Rancangan Model Bisnis Ketahanan Pangan Di Lahan Gambut Untuk PEN Food Estate LHK. Kementrian Lingkungan Hidup Dan Kehutanan. http://pen.menlhk.go.id/detail/32

Saputro, G. E., \& Meirinaldi. (2019). Analisis Pengaruh Stabilitas Keamanan dan Pertumbuhan Industri Strategis Terhadap Makroekonomi. JURNAL EKONOMI, 237-238. https://doi.org/https://doi.org/10.37721/je.v21i3.603

Saputro, G. E., \& Meirinaldi, M. (2021). Pengaruh Stabilitas Makro Ekonomi, Stabilitas Keamanan Dan Pertumbuhan Industri Strategis Terhadap Pertumbuhan Ekonomi. JURNAL EKONOMI, 23(1), 2. 
https://doi.org/10.37721/je.v23i1.757

Saputro, G. E., Rivai, A. M., \& Meirinaldi. (2021). Pengaruh Anggaran Pertahanan, Impor Alutsista, Ekspor Alutsista, Dan Inflasi Terhadap Pertumbuhan Ekonomi Di Indonesia Tahun 1980-2019. JURNAL EKONOMI, 23(2), 103. https://doi.org/https://doi.org/10.37721/je.v23i2.801

Saputro, G. E., Tarigan, H., \& Rajab, D. D. A. (2021). THE ROLE OF DEFENSE ECONOMIC IN ECONOMIC GROWTH. Jurnal Pertahanan, 7(2), 330. https://doi.org/10.33172/jp.v7i2.1239

Sugiyono. (2005). Memahami Penelitian Kualitatif. CV. Alfabeta.

Supriyatno. (2017). Tentang Perang Bagian I Terjemahan “On War" Carl Von Clausewitz (Vol. 1). Makmur Cahaya Ilmu.

Wulandari, B. R. D., \& Anggraini, W. (2020). Food Estate Sebagai Ketahanan Pangan Di Tengah Pandemi Covid19 Di Desa Wanasaba. Jurnal Pengabdian Masyarakat Berkemajuan, 4(1), 387. https://doi.org/https://doi.org/10.31764/jpmb.v4i1.3062

Yusgiantoro, P. (2014). Ekonomi Pertahanan Teori Dan Praktik. Gramedia Pustaka Utama. 